\title{
Morfologi Debunga Lima Genus Terpilih Sapindaceae di Semenanjung Malaysia
}

(Pollen Morphology of Five Selected Genera of Sapindaceae in Peninsular Malaysia)

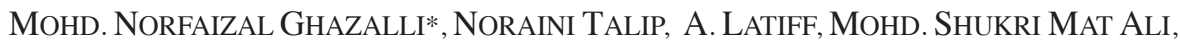 \\ AHMAD ZAKI ZAINI \& NURSHAHIDAH MOHD RUSLI
}

\begin{abstract}
ABSTRAK
Kajian morfologi debunga untuk enam spesies dan lima genus dalam empat tribus di dalam famili Sapindaceae telah dijalankan menerusi pemerhatian mikroskop elekron imbasan. Sebanyak tujuh ciri morfologi debunga telah dikenal pasti boleh digunakan untuk membezakan spesies kajian iaitu jenis debunga, saiz debunga, bentuk debunga, ciri ambitus, variasi nisbah C/P, variasi indeks kawasan kutub d/D dan ciri hiasan eksin. Dua kelas debunga yang direkodkan hadir ialah trikolporat dan triporat dengan dua bentuk debunga juga telah dikenal pasti hadir pada spesies yang dikaji iaitu bentuk segitiga dan prolat. Kajian ini menunjukkan terdapat dua ciri diagnosis dicerap iaitu jenis debunga triporat pada Guioa pleuropteris dan julat d/D butir debunga (Lepisanthes tetraphylla) yang kecil iaitu kurang daripada 0.25 boleh digunakan untuk membezakan spesies-spesies Sapindaceae kajian secara langsung.
\end{abstract}

Kata kunci: Debunga; morfologi; Sapindaceae; Semenanjung Malaysia

\section{ABSTRACT}

Pollen morphological study of six species and five genera in four tribes of Sapindaceae family was undertaken using scanning electron microscope. Seven pollen characteristics were identified to be useful in differentiating these species such as pollen type, pollen size, pollen shape, ambitus characters, variation in C/P ratio, variation in d/D pollen polar index and exine ornamentations. Two pollen classes were recorded in this study, i.e. tricolporate and triporate, while two pollen shapes were also identified namely triangle and prolate. Two diagnostic characters found useful in species identification were obtained from this study, i.e. triporate pollen type (Guioa pleuropteris) and small d/D ratio of less than 0.25 (Lepisanthes tetraphylla).

Keywords: Morphology; pollen; Peninsular Malaysia; Sapindaceae

\section{Pengenalan}

Sapindaceae merupakan salah satu famili tumbuhan berbunga yang utama dengan jumlah kepelbagaian spesiesnya merangkumi 141 genus dengan 1900 spesies di seluruh dunia. Sebanyak 135 genus dan 1500 spesies boleh ditemui di kawasan tropika dan sub-tropika, terutamanya di Asia Tenggara (Adema et al. 1996; Xia \& Gadek 2007). Kajian morfologi debunga Sapindaceae khususnya yang melibatkan hampir $70 \%$ spesies temperat telah dilakukan oleh Muller dan Leenhouts (1976). Kebanyakan usaha pemerhatian untuk menganalisis jenis debunga dan perkaitannya dengan hubungan sistematik tumbuhan. Kajian selanjutnya juga pernah dilakukan oleh van der Ham (1990), Avecedo-Rodriguez (1993) dan Ferruci dan Anzotegui (1993) melibatkan beberapa genus dan spesies seperti Serjania, Mellicoccus dan Talisia namun tidak secara menyeluruh.

Penilaian terbaru ke atas famili Sapindaceae yang dilakukan oleh Thorne dan Reveal (2007) melibatkan pentaksiran semula spesies yang telah dan sedang dihuraikan dengan mencadangkan 1900 spesies yang terdiri daripada 141 genus. Radlkolfer (1934) mengiktiraf 14 tribus dalam Sapindaceae iaitu lima tribus di dalam
Dodonaeiodeae dan sembilan tribus di dalam Sapindoideae. Buerki et al. (2009) pula mengalami kesukaran untuk meletakkan sembilan genus di dalam empat tribus yang sedia ada dan berpendapat untuk meletakkan semua genus tersebut ke dalam tribus baru iaitu Harpullieae. Menerusi kumpulan baru yang bersifat heterogen ini, mereka kemudiannya menempatkan genus ini kepada dua kumpulan berpandukan kepada kehadiran anak daun terminal iaitu Ungnandia Endl. dan Xanthocheras Bunge dan ketidakhadiran anak daun terminal (Arfeuillea Pierre, Conchopetalum, Eurycorymbus Hand. \& Mazz., Harpullia Roxb., Magonia A. St. Hil. dan Majidea J. Kirk. ex Oliv.). Berdasarkan semakan semula sistem infra-famili oleh Radlkolfer (1934) yang berpandukan kepada ciri morfologi dan debunga, Muller dan Leenhouts (1976) bersependapat untuk mengembangkan tribus Harpulliae dengan kemasukan tiga genus lagi iaitu Aesculus L., Billia Peyr. dan Handeliodendron Rehdr. Mereka seterusnya menghuraikan secara terperinci perkaitan antara Hipposcastanaceae dan Harpulliae yang melibatkan dua genus, Handeliodendron Rehdr. dan Delavaya Franch.

Kajian awal morfologi debunga oleh Muller dan Leenhouts (1976) mendapati bentuk umum butiran 
debunga Sapindaceae adalah isokutub atau sub-isokutub monad. Butiran debunga jenis tetrad hanya dicerap pada Magonia A. St. hill (Avecedo et al. 2011). Kajian ini juga mendapati saiz kebanyakan debunga Sapindaceae adalah pada julat 20-30 $\mu \mathrm{m}$, dengan ciri bukaan 2- ke 4- apertur. Kelas debunga kolporat lebih lazim ditemui dan ia merupakan kelas debunga asas famili ini. Kelas debunga sinkolporat dan parasinkolporat dapat dicerap pada subfamili Sapindoideae, tribus Cupanieae (Alectryon Benth., Schleichera Lour., Castanospora F. Muell., Tristira Radlk. dan Tristiropsis Radlk.). Ciri bukaan kecil pada debunga jenis porat dan brevikolporat pula dapat diperhatikan pada beberapa spesies seperti Allophyllus L., Lepisanthes Blume, Pometia J.R. Forst. \& G. Forst. dan Tallisia Aubl. yang merangkumi tribus Paullinieae.

Kajian palinologi di dalam bidang taksonomi tumbuhan merupakan kajian yang masih kurang diberikan perhatian di Malaysia disebabkan faktor kesukaran mendapatkan sampel bunga. Oleh yang demikian, kajian palinologi ke atas famili Sapindaceae amat diperlukan untuk memperoleh data ciri morfologi debunga yang boleh digunakan sebagai ciri tambahan pengecaman spesies dan juga genus serta pencirian morfologi debunga bagi Sapindaceae.

\section{BAHAN DAN KAEDAH}

Kajian ini melibatkan enam spesies daripada genus Allophyllus, Cardiospermum L., Glenniea Hook. f., Guioa dan Lepisanthes. Gabungan sampel segar dan sampel kering telah digunakan dalam kajian ini dan spesimen segar diperoleh dari beberapa lokaliti di Semenanjung Malaysia (Jadual 1). Sebanyak tiga replikasi telah digunakan di dalam kajian ini yang melibatkan pengukuran dan pentafsiran butiran debunga di bawah pemerhatian mikroskop elektron imbasan. Ciri debunga dicerap dan dihuraikan mengikut kaedah huraian Erdtman (1952), Kremp (1965) dan Reitsma (1966). Kaedah asetolisis diaplikasikan mengikut Erdtman (1952). Cerapan dibuat di bawah mikroskop imbasan elektron model Zeiss Supra 55VP. Imej kemudiannya dicetak untuk analisis lanjut di bawah beberapa siri pembesaran 2000× sehingga 15000×. Huraian ciri morfologi debunga dilakukan berdasarkan kaedah huraian oleh Erdtman (1969), Faegri dan Iversen (1992), Kremp (1965) dan Moore et al. (1978). Istilah yang digunakan bagi kelas debunga merujuk kepada Erdtman (1969, 1952), Hesse et al. (2009), Kremp (1965), Moore et al. (1991), Punt et al. (1994) dan Reitsma (1966). Jenis debunga (debunga typology) pula dihuraikan menurut Sistem Analisis-Bilangan-Kedudukan-Jenis (NumberPosition-Character-Analysis, NPC-Analysis).

\section{HASIL DAN PERBINCANGAN}

Allophyllus cobbe (L.) Raeusch. Kelas: trikolporat. Nisbah P/E: 2.15. Bentuk: segitiga. Nisbah C/P: 0.66. Nisbah d/D: 0.73. Apertur: kolpus. Ambitus: membulat. Hiasan eksin: striat. Saiz: ukuran pada pandangan kutub (P) 19.73 (23.92) $27.05 \mu \mathrm{m}$, ukuran pada pandangan khatulistiwa (E) 8.42 (11.08) $13.18 \mu \mathrm{m}$, panjang kolpus (C) 15.01 (15.98) $18.31 \mu \mathrm{m}$, panjang apokolpium (d) 7.15 (8.81) $9.06 \mu \mathrm{m}$, diameter pada pandangan kutub (D) 11.34 (12.03) 12.33 $\mu \mathrm{m}$ (Rajah 1(A)-1(D)).

Cardiospermum halicacabum L. Kelas: trikolporat. Nisbah P/E: 1.54. Bentuk: segitiga. Nisbah C/P: 0.81. Nisbah d/D: 0.60. Apertur: porus. Ambitus: membulat cembung. Hiasan eksin: retikulat. Saiz: ukuran pada pandangan kutub (P) 27.84 (32.81) $35.56 \mu \mathrm{m}$, ukuran pada pandangan khatulistiwa (E) 20.02 (21.32) $21.93 \mu \mathrm{m}$, panjang porus (C) 25.64 (26.73) $27.88 \mu \mathrm{m}$, panjang apokolpium (d) 8.00 (8.89) $10.21 \mu \mathrm{m}$, diameter pada pandangan kutub (D) 13.88 (14.63) $15.07 \mu \mathrm{m}$ (Rajah 1(E)-1(H)).

Glenniea penangensis (Ridl.) Leenh. Kelas: trikolporat. Nisbah P/E: 2.06. Bentuk: segitiga. Nisbah C/P: 0.61. Nisbah d/D: 0.50. Apertur: kolpus. Ambitus: segitiga. Hiasan eksin: striat. Saiz: ukuran pada pandangan kutub (P) 16.81 (18.79) $7.8 \mu \mathrm{m}$, ukuran pada pandangan khatulistiwa (E) 5.91 (7.04) $8.06 \mu \mathrm{m}$, panjang kolpus (C) 10.35 (11.37) $12.13 \mu \mathrm{m}$, panjang apokolpium (d) $5.16(6.11) 7.81 \mu \mathrm{m}$, diameter pada pandangan kutub (D) 11.48 (12.13) 13.04 $\mu \mathrm{m}$ (Rajah 2(A)-2(D)).

Guioa pleuropteris Radlk. Kelas: triporat. Nisbah P/E: 1.68. Bentuk: prolat. Nisbah C/P: 0.56. Nisbah d/D: 0.59. Apertur: porus. Ambitus: membulat rata. Hiasan eksin: striat. Saiz: ukuran pada pandangan kutub (P) 21.51 (7.52) $25.45 \mu \mathrm{m}$, ukuran pada pandangan khatulistiwa (E) 11.09 (12.74) $13.62 \mu \mathrm{m}$, panjang porus (C) 12.47 (13.04) $13.25 \mu \mathrm{m}$, panjang apokolpium (d) 2.98 (4.57) $6.93 \mu \mathrm{m}$, diameter pada pandangan kutub (D) 6.69 (7.75) $9.56 \mu \mathrm{m}$ (Rajah 2(E)-2(H)).

Lepisanthes fruticosa (Roxb.) Leenh. Kelas: trikolporat. Nisbah P/E: 1.52. Bentuk: prolat. Nisbah C/P: 0.51. Nisbah d/D: 0.26. Apertur: kolpus. Ambitus: membulat rata. Hiasan eksin: retikulat. Saiz: ukuran pada pandangan kutub (P) 19.67 (23.36) $29.33 \mu \mathrm{m}$, ukuran pada pandangan khatulistiwa (E) 9.49 (15.35) $7.77 \mu \mathrm{m}$, panjang kolpus (C) 10.19 (12.04) $13.05 \mu \mathrm{m}$, panjang apokolpium (d) 3.32 (3.58) $4.15 \mu \mathrm{m}$, diameter pada pandangan kutub (D) 9.67 (13.43) $14.27 \mu \mathrm{m}$ (Rajah 3(A)-3(D)).

Lepisanthes tetraphylla Radlk. Kelas: trikolporat. Nisbah P/E: 1.35. Bentuk: oblat. Nisbah C/P: 0.53. Nisbah d/D: 0.24. Apertur: kolpus. Ambitus: membulat rata. Hiasan eksin: skabrat. Saiz: ukuran pada pandangan kutub (P) 16.04 (23.47) $27.95 \mu \mathrm{m}$, ukuran pada pandangan khatulistiwa (E) 12.76 (17.35) $20.18 \mu \mathrm{m}$, panjang kolpus (C) 10.81 (12.51) $13.76 \mu \mathrm{m}$, panjang apokolpium (d) 2.05 (3.31) $4.34 \mu \mathrm{m}$, diameter pada pandangan kutub (D) 11.47 (13.65) $15.84 \mu \mathrm{m}$ (Rajah 3(E)-3(I)). 


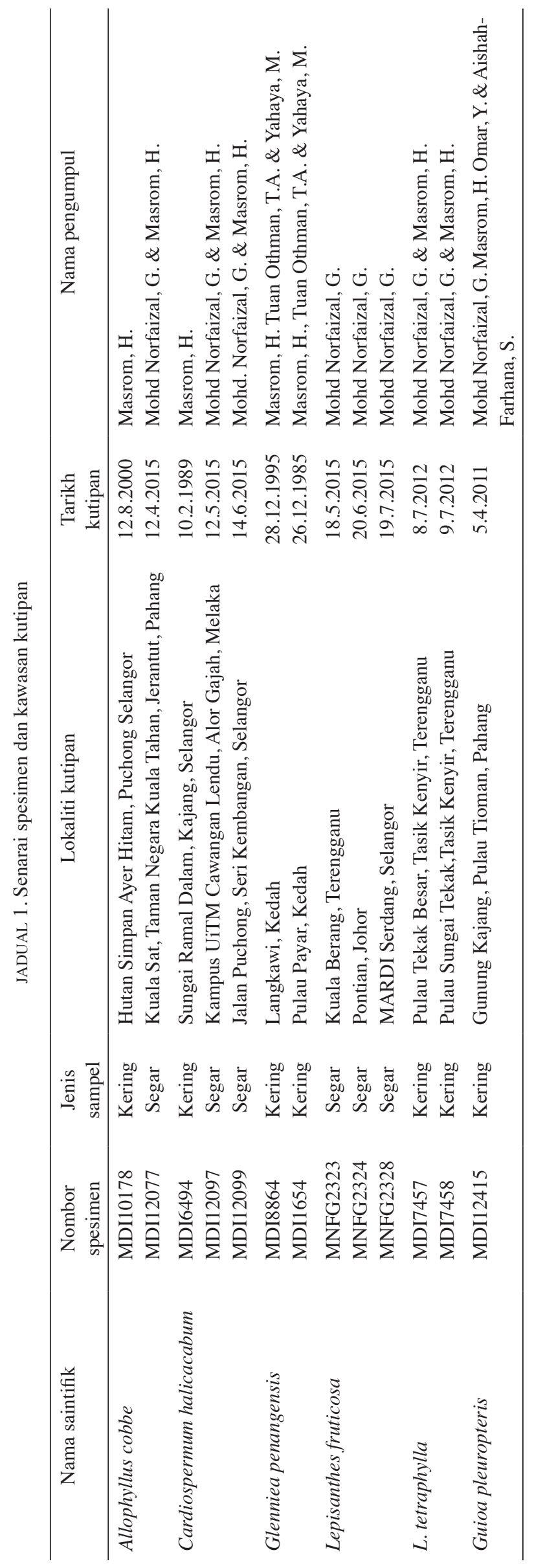



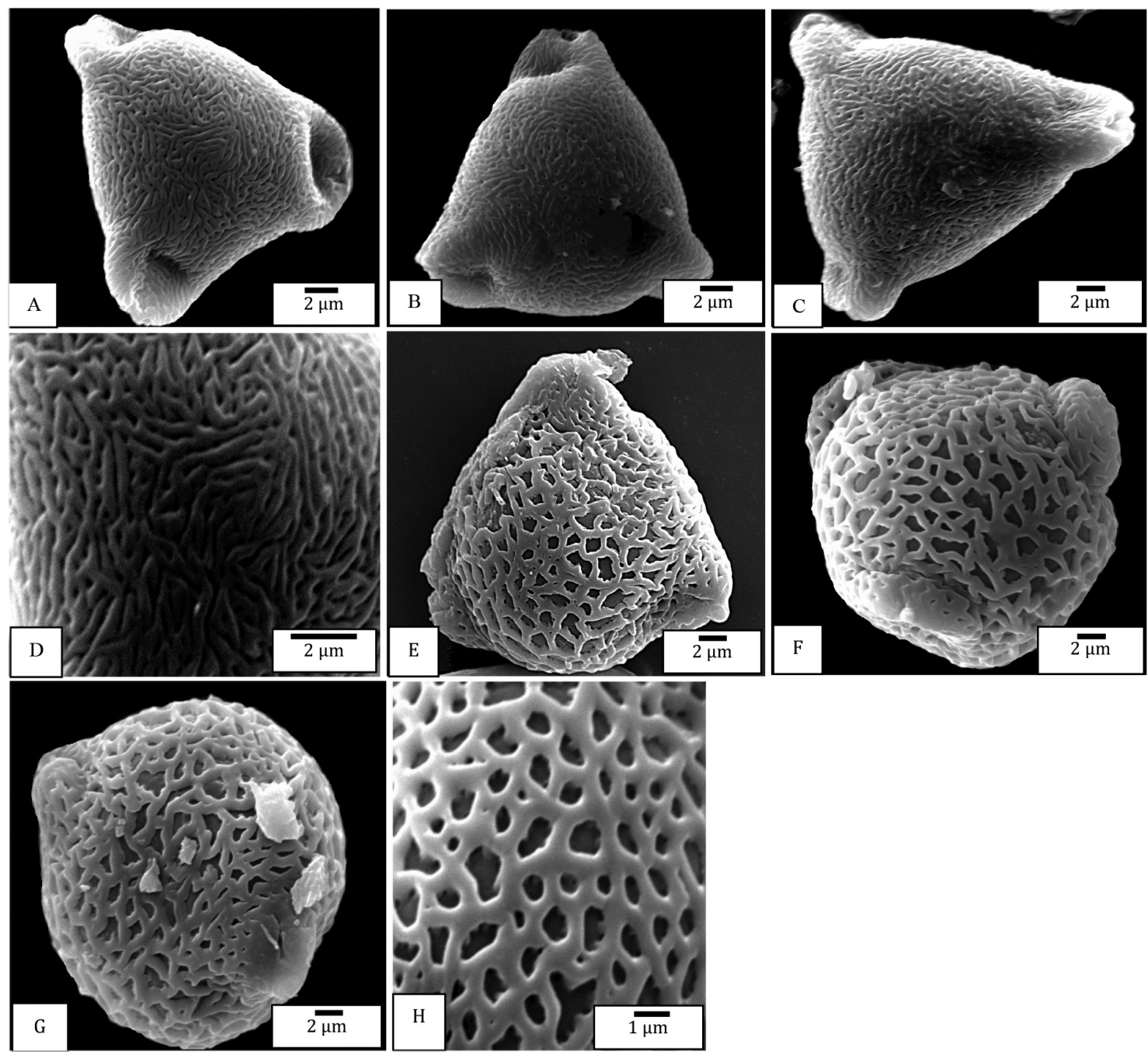

RAJAH 1. Ciri morfologi debunga di bawah mikroskop imbasan elektron, Allophyllus cobbe: A dan B Pandangan kutub, C Pandangan khatulistiwa, D Hiasan eksin. Cardiospermum halicacabum: E dan F Pandangan kutub, G Pandangan khatulistiwa, dan H Hiasan eksin. Skala: A-G $=2 \mu \mathrm{m}, \mathrm{H}=1 \mu \mathrm{m}$

\section{PERBINCANGAN}

Kepelbagaian morfologi debunga Sapindaceae khususnya yang melibatkan spesies temperat telah dibincangkan secara terperinci oleh Muller dan Leenhouts (1976) dan kebanyakannya melibatkan penggunaan spesimen herbarium. Kepelbagaian bentuk debunga yang tinggi ditunjukkan oleh Serjania Plum. ex Schum. dan Allophylastrum Avec. Rodr. dalam famili Sapindaceae (Avecedo-Rodriguez 2011). Terdapat variasi pada ciri kelas debunga dan empat kelas debunga telah dikenal pasti. Kelas debunga boleh ditentukan berdasarkan bilangan, kedudukan dan ciri khusus apertur. Kelas debunga merupakan ciri yang amat penting untuk dikaji kerana ia merupakan perkara asas yang ditentukan kajian palinologi (Muller 1979; van der Ham 1990). Hasil kajian ini membuktikan bahawa ciri kelas debunga mempunyai nilai signifikan yang tinggi dalam pengelasan genus dalam famili Sapindaceae (Jadual 2).

Dua kelas debunga yang direkodkan hadir ialah trikolporat dan triporat (Jadual 2). Spesies Allophyllus cobbe,
Cardiospermum halicacabum, Glenniea penangensis, $L$. tetraphylla dan L. fruticosa menunjukkan kelas debunga jenis trikolporat, manakala Guioa pleuropteris pula adalah kelas debunga jenis triporat dicerap. Menurut Ferruci dan Anzotegui (1993), kelas debunga memainkan peranan yang penting dalam penentuan dan pengecaman sesuatu spesies sehingga ke peringkat genus dan spesies seperti kajian ke atas Serjania, Houssayanthus Hunz. dan Urvillea Kunth. Pendapat yang sama juga diutarakan oleh Furness (1989) melalui pemerhatian butir debunga famili Acanthaceae.

Saiz debunga yang dicerap memainkan peranan yang penting di dalam proses pentaksiran data kajian palinologi dan morfologi tumbuhan. Ashton (1982) dan Noraini (2008) membuktikan hubungan dan pertalian yang rapat antara saiz debunga dengan saiz bunga bagi sesuatu spesies, iaitu bunga yang bersaiz besar lebih cenderung untuk mempunyai saiz debunga yang besar, dan begitulah sebaliknya. Kajian yang dijalankan oleh Avecedo (2003) juga menyimpulkan bahawa saiz debunga bagi sesuatu famili adalah seragam seperti saiz debunga untuk genus 

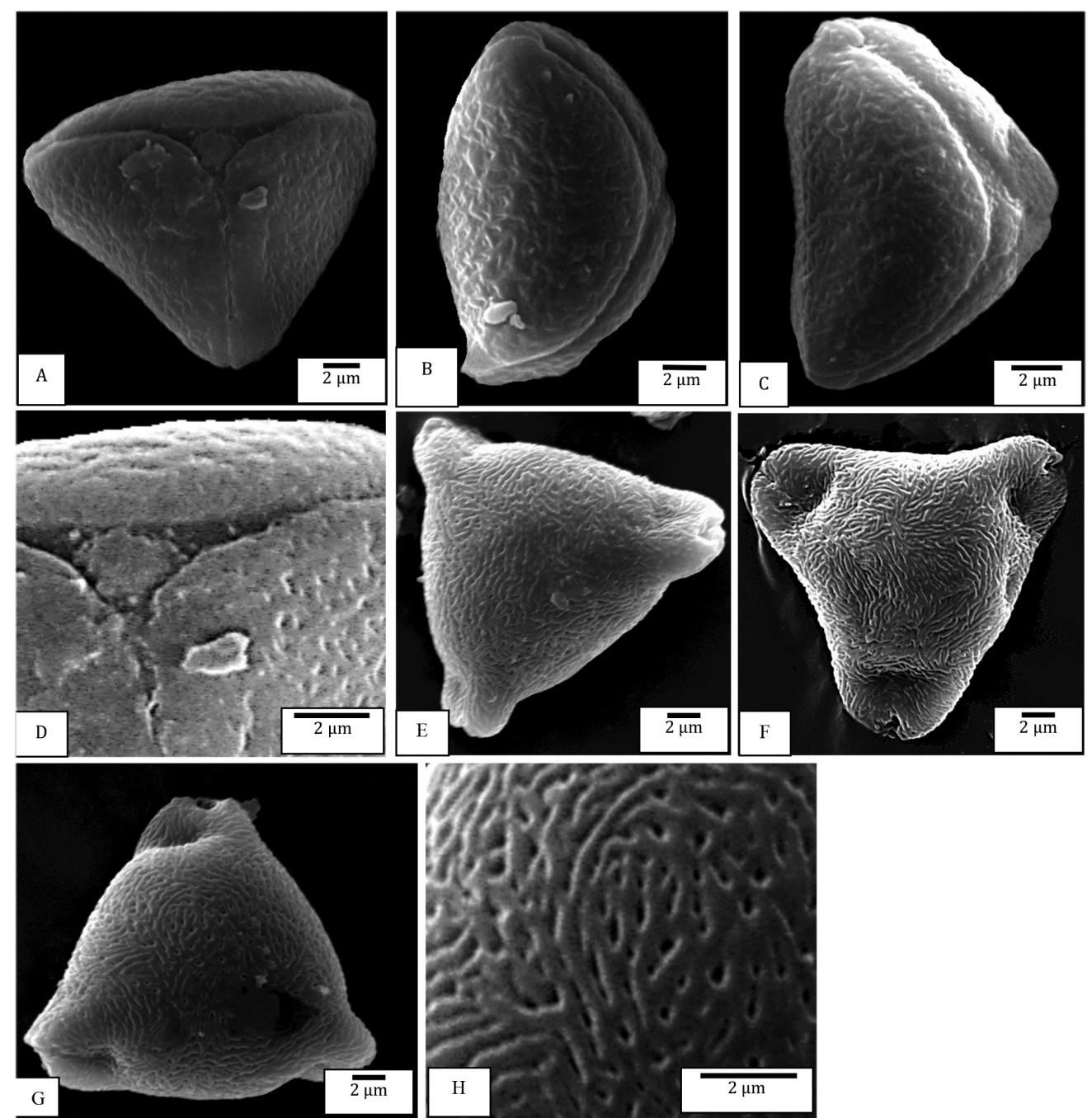

RAJAH 2. Ciri morfologi debunga di bawah mikroskop imbasan elektron, Glenneia penangensis: A Pandangan kutub, B dan C Pandangan khatulistiwa, D Hiasan eksin pada debunga. Guioa pleuropteris: E Pandangan kutub,

F dan G Pandangan khatulistiwa, dan H Hiasan eksin pada debunga. Skala: A-H $=2 \mu \mathrm{m}$

Magonia A. St. Hill., Alectryon dan genus lain yang menunjukkan saiz sekitar 20-30 $\mu \mathrm{m}$. Pengukuran dan penentuan saiz debunga secara relatif iaitu bersaiz kecil, sederhana dan besar adalah mengikut Erdtman (1969) dan Hesse et al. (2009).

Hasil kajian ini menyokong penemuan hasil kajian terdahulu ke atas famili Sapindaceae di kawasan temperat oleh Avecedo (1993), van der Ham (1990) dan Wang dan Chien (1956) yang menyatakan julat saiz debunga untuk kebanyakan spesies adalah sekitar 20-30 $\mu \mathrm{m}$, kecuali untuk beberapa genus iaitu Dimocarpus Lour., Nephelium L., Glenniea dan Xerospermum Blume yang menunjukkan kehadiran debunga bersaiz kecil iaitu sekitar 10-15 $\mu \mathrm{m}$. Muller (1979) berpendapat variasi pada saiz debunga spesies tumbuhan mempunyai hubung kait dengan proses pendebungaan. Pendapat ini dibuktikan oleh Erdtman (1952), Moore et al. (1991) dan Nowicke dan Skvarla (1979) yang menyatakan bahawa ciri dan saiz debunga sesuatu spesies secara fizikalnya amat dipengaruhi oleh pelbagai faktor seperti pendebungaan, penyebaran dan percambahan. Nisbah panjang kutub $(\mathrm{P})$ dan panjang paksi khatulistiwa (E) merupakan petunjuk untuk menentukan indeks dan bentuk sesuatu debunga (Erdtman 1969). Bacaan nilai $\mathrm{P} / \mathrm{E}$ ini amat penting terutamanya untuk kajian filogenetik dan spesiesomi tumbuhan kerana ia boleh digunakan dalam menentukan bentuk debunga sesuatu spesies tumbuhan (Noraini 2008, 2006). Pernyataan ini dicerap melalui julat nisbah bacaan panjang $(\mathrm{P})$ dibahagikan dengan nilai diameter (E) iaitu P/E. Hasil kajian ini merekodkan kehadiran variasi yang tinggi bagi bentuk debunga pada tujuh spesies yang dikaji (Jadual 3). Analisis ini menunjukkan bahawa bentuk debunga adalah agak seragam dan tidak menunjukkan variasi yang ketara. Dua bentuk debunga telah dikenal pasti hadir pada spesies yang dikaji iaitu bentuk segitiga dan prolat. Bentuk debunga segitiga ditunjukkan oleh majoriti spesies kajian daripada Allophyllus, Cardiospermum, Glenniea dan Lepisanthes. Guioa pula menunjukkan bentuk debunga prolat. Hasil kajian ini menyokong penemuan kajian yang dijalankan oleh Wang dan Chien (1956) yang mendapati 

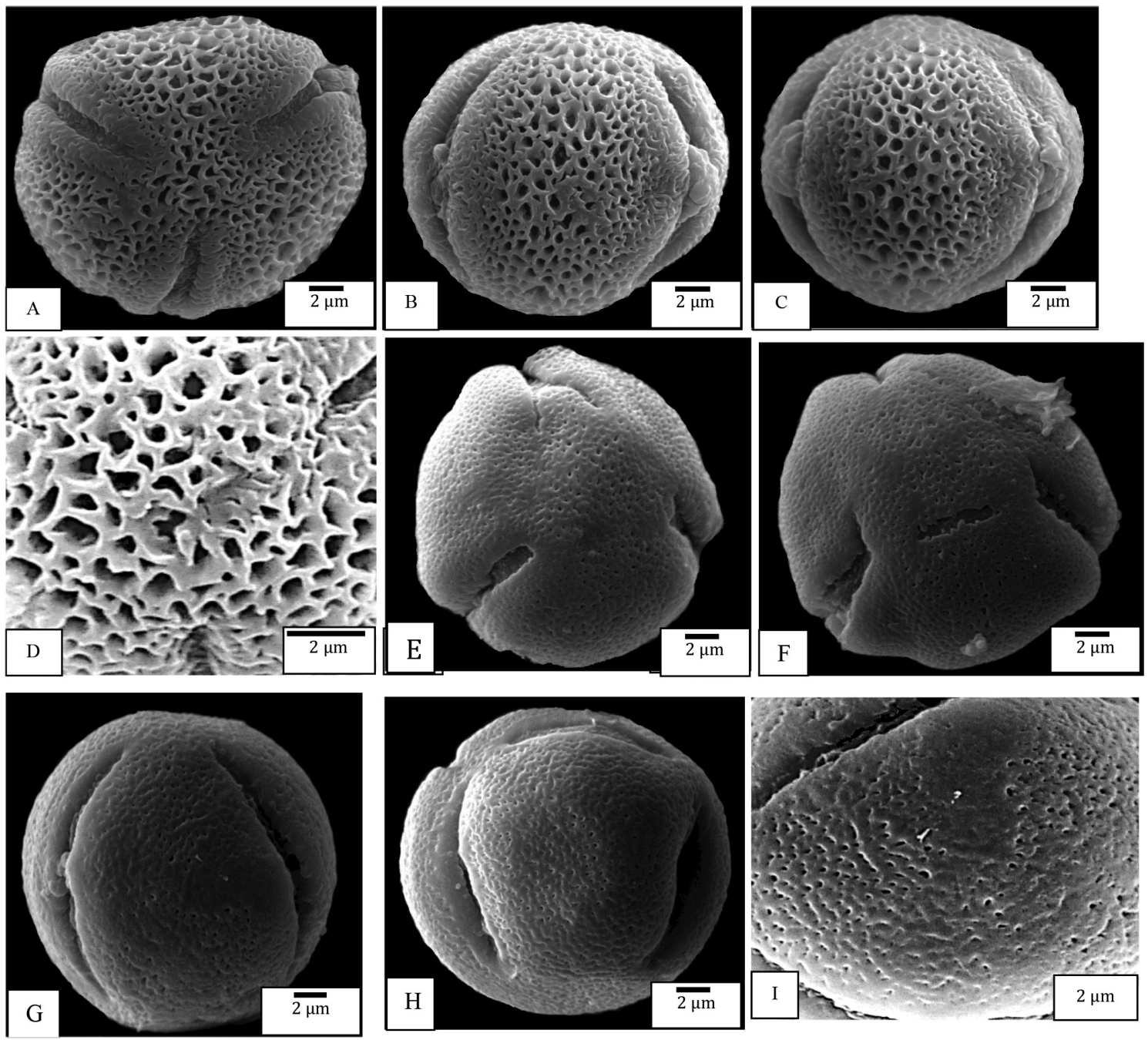

RAJAH 3. Ciri morfologi debunga di bawah mikroskop imbasan elektron Lepisanthes fruticosa: A Pandangan kutub, B dan C Pandangan khatulistiwa, D Hiasan eksin pada debunga. Lepisanthes tetraphylla: E dan F Pandangan kutub, $\mathrm{G}$ dan H Pandangan khatulistiwa, I Hiasan eksin pada debunga. Skala: A-E: $2 \mu \mathrm{m}, \mathrm{A}-\mathrm{I}=2 \mu \mathrm{m}$

JADUAL 2. Jadual pengelasan jenis dan saiz debunga berdasarkan kedudukan spesies dalam subfamili dan tribus

\begin{tabular}{|c|c|c|c|c|}
\hline Spesies & Tribus & Jenis debunga & $\begin{array}{l}\text { Relatif dan julat ukuran } \\
\text { saiz debunga }(\mu \mathrm{m})\end{array}$ & $\begin{array}{c}\text { Julat ukuran saiz } \\
\text { debunga kajian } \\
(\mu \mathrm{m})\end{array}$ \\
\hline Glenniea penangensis & Lepisanthaeae & Trikolporat & $\begin{array}{c}\text { Kecil } \\
(10-25 \mu \mathrm{m})\end{array}$ & $15-19$ \\
\hline Lepisanthes fruticosa & Lepisanthaeae & Trikolporat & $\begin{array}{l}\text { Sederhana besar } \\
\quad(25-50 \mu \mathrm{m})\end{array}$ & $20-26$ \\
\hline L. tetraphylla & Lepisanthaeae & Trikolporat & & $20-26$ \\
\hline Allophyllus cobbe & Thouineae & Trikolporat & & $20-23$ \\
\hline Cardiospermum halicacabum & Paullineae & Trikolporat & & $7-25$ \\
\hline Guioa pleuropteris & Cupanieae & Triporat & & $7-26$ \\
\hline
\end{tabular}

ciri variasi bentuk debunga Sapindaceae di China dan ciri ini didapati menepati kajian terdahulu morfologi debunga oleh Muller (1979) ke atas beberapa spesies
Sapindaceae temperat. Oleh yang demikian, gabungan pelbagai ciri morfologi debunga termasuk bentuk debunga menunjukkan kepentingannya dalam kajian sistematik. 
Kepentingan penelitian ke atas ciri ambitus ini boleh dilihat melalui kajian Ortrud dan Cynthia (2014) ke atas famili Vochysiaceae dan hasil kajian itu menunjukkan bahawa pandangan kutub spesies kajian mempunyai nilai sistematik untuk pengelasan genus. Hasil kajian ini menunjukkan dua ciri ambitus dicerap hadir pada spesies. Ciri ambitus segitiga pula hadir pada Allophyllus, Glenniea dan Lepisanthes manakala ciri ambitus bulat dicerap pada Cardiospermum, Guioa dan Lepisanthes (Jadual 3).

Indeks panjang kolpus merupakan satu lagi ciri yang penting dan nilai panjang kolpus boleh digunakan sebagai asas untuk mengukur panjang kolpus daripada nisbah $\mathrm{C} / \mathrm{P}$. Indeks panjang kolpus didapati mempunyai nilai sistematik ke atas morfologi debunga Rosa (Rosaceae) (Wronska-Pilarek \& Lira 2006; Wronska-Pilarek \& Boraynska 2005). Pendapat ini juga bersamaan dengan pandangan Noraini (2008) dalam kajiannya ke atas debunga daripada Shorea, Hopea, Parashorea dan Neobalanocarpus (Dipterocarpaceae) di Malaysia yang mendapati bahawa indeks panjang kolpus bagi genusgenus yang dinyatakan di atas mempunyai nilai sistematik yang tinggi.

Indeks kawasan kutub dikira berdasarkan daripada nisbah d/D mempunyai nilai sistematik dalam membezakan spesies yang dikaji. Kajian terdahulu oleh Noraini (2008) ke atas famili Dipterocarpaceae mendapati ciri ini mempunyai nilai sistematik yang tinggi untuk pengecaman genus Shorea, Hopea, Parashorea dan Neobalanocarpus. Hasil kajian ke atas Sapindaceae ini juga berjaya mengelompokkan indeks kawasan kutub berdasarkan julat $\mathrm{d} / \mathrm{D}$ kepada tiga perbandingan nilai indeks secara relatif iaitu kecil, sederhana dan besar. Indeks bagi kawasan kutub boleh ditentukan melalui nisbah d/D. Hasil kajian ini menunjukkan Lepisanthes yang mempunyai nisbah d/D yang kecil iaitu di bawah julat $<0.25$ manakala Allophyllus, Glenniea dan dua spesies Lepisanthes menunjukkan nisbah d/D yang sederhana besar iaitu 0.50-0.75. Genus Cardiospermum dan Guioa menunjukkan nisbah d/D yang besar iaitu 0.50 1.00. Oleh itu, nisbah d/D boleh memberi nilai signifikan dalam membezakan spesies sehingga ke peringkat genus bagi famili Sapindaceae (Jadual 4).

Morfologi pada bahagian dinding debunga terdiri daripada dua lapisan yang dikenali dengan lapisan dalaman yang dipanggil intin manakala lapisan luar yang luar dikenali sebagai eksin (Reitsma 1966). Ciri variasi yang hadir pada dinding debunga sangat penting dalam membantu pengecaman sesuatu spesies tumbuhan (Eide 1981; Fogle 1977; Shinwari \& Khan 2004). Hasil kajian ini merekodkan variasi yang sederhana tinggi pada ciri hiasan eksin bagi kesemua spesies kajian. Pengecaman ciri hiasan eksin yang dilakukan melalui cerapan jenis hiasan dinding eksin dan juga pada kehadiran apertur

JADUAL 3. Bentuk debunga dan ciri amb yang hadir pada spesies Sapindaceae kajian

\begin{tabular}{lccc}
\hline \multicolumn{1}{c}{ Spesies } & $\begin{array}{c}\text { Bentuk } \\
\text { debunga }\end{array}$ & $\begin{array}{c}\text { Julat nisbah P/E ukuran } \\
\text { debunga } \\
(1.00-3.00)\end{array}$ & Ciri amb \\
\hline Allophyllus cobbe & Segitiga & 2.26 & Segitiga \\
Glenniea penangensis & Segitiga & 1.65 & Segitiga \\
Lepisanthes tetraphylla & Prolat & 1.51 & Segitiga \\
Cardiospermum halicacabum & Segitiga & 1.68 & Bulat \\
Guioa pleuropteris & Prolat & 2.72 & Bulat \\
L.fruticosa & Prolat & 1.17 & \\
\hline
\end{tabular}

JADUAL 4. Variasi indeks kawasan kutub d/D dan nisbah C/P pada spesies Sapindaceae kajian

\begin{tabular}{lccccc}
\hline \multicolumn{1}{c}{ Spesies } & $\begin{array}{c}\text { Perbandingan } \\
\text { nilai indeks secara } \\
\text { relatif }\end{array}$ & Julat d/D & $\begin{array}{c}\text { Purata C } \\
(\mu \mathrm{m})\end{array}$ & $\begin{array}{c}\text { Purata P } \\
(\mu \mathrm{m})\end{array}$ & Nisbah C/P \\
\hline Lepisanthes tetraphylla & Kecil & $<0.25$ & 13.04 & 23.47 & 0.53 \\
Allophyllus cobbe & Sederhana & $0.25-0.50$ & 11.37 & 18.79 & 0.61 \\
Glenniea penangensis & Sederhana & & 11.37 & 18.79 & 0.61 \\
Lepisanthes fruticosa & Sederhana & & 12.04 & 23.36 & 0.51 \\
Cardiospermum halicacabum & Besar & $0.50-1.00$ & 26.73 & 32.81 & 0.81 \\
Guioa pleuropteris & Besar & & 12.51 & 7.52 & 0.56 \\
\hline
\end{tabular}


JADUAL 5. Variasi hiasan eksin yang dicerap pada spesies Sapindaceae kajian

\begin{tabular}{|c|c|c|}
\hline Spesies & Hiasan eksin & Gambarajah \\
\hline \multirow[t]{2}{*}{$\begin{array}{l}\text { Allophyllus cobbe } \\
\text { Glenniea penangensis } \\
\text { Guioa pleuropteris }\end{array}$} & $\begin{array}{l}\text { Striat } \\
\text { (hiasan seakan rabung kasar pada } \\
\text { permukaan debunga) }\end{array}$ & \\
\hline & Retikulat & \\
\hline $\begin{array}{l}\text { Lepisanthes fruticosa } \\
\text { Cardiospermum halicacabum }\end{array}$ & $\begin{array}{l}\text { (hiasan seakan lubang broki } \\
\text { pada permukaan debunga) }\end{array}$ & \\
\hline Lepisanthes tetraphylla & $\begin{array}{l}\text { Skabrat } \\
\text { (permukaan debunga kasar dengan } \\
\text { ketebalan kurang } 0.5 \mu \mathrm{m} \text { ) }\end{array}$ & Netase \\
\hline
\end{tabular}

yang terdapat pada debunga yang dikaji. Hasil kajian ini telah mengenal pasti tiga jenis hiasan eksin pada enam spesies Sapindaceae kajian (Jadual 5), iaitu striat, skabrat dan retikulat. Corak hiasan jenis retikulat ditunjukkan oleh Cardiospermum halicacabum dan Lepisanthes fruticosa manakala L. tetraphylla menunjukkan ciri hiasan skabrat, dan corak hiasan striat ditunjukkan oleh Allophyllus cobbe, Glenneia penangensis dan Guioa pleuropteris. Hasil gabungan kajian terdahulu dengan kajian ini dapat jelas membuktikan kepentingan jenis hiasan eksin yang hadir pada debunga dan ciri ini sememangnya mempunyai nilai sistematik yang tinggi terutamanya untuk pembezaan dan pengecaman spesies dan genus.

Analisis berangka fenetik yang dilakukan ke atas spesies kajian menunjukkan Guioa pleuropteris terasing membentuk ahli kumpulan luar dengan Indeks Kesamaan 0.49 (Rajah 4). Tiga kumpulan utama telah dikenal pasti iaitu Cardiospermum halicacabum dengan Indeks Kesamaan 0.40, kumpulan kedua terdiri daripada $L$. tetraphylla dan L. fruticosa (0.81), dan kumpulan ketiga terdiri daripada Glenneia penangensis dan Allophyllus cobbe (0.87). Perbezaan yang utama dikenal pasti menyebabkan Guioa pleuropteris terasing membentuk kumpulan luar dengan ciri kelas debunga triporat yang berbeza dengan spesies kajian lain dan hasil kajian ini menyokong pendapat Avecedo-Rodriguez (2003) yang menyatakan ciri kelas debunga memainkan peranan asas yang penting untuk pembezaan spesies dan genus.

Selain itu, ciri diagnosis merupakan ciri unik yang dicerap pada satu spesies sahaja dan tidak dapat diperhatikan pada spesies-spesies lain serta mempunyai nilai sistematik yang sangat berguna untuk pengecaman spesies secara langsung. Hasil kajian ini merekodkan dua ciri diagnosis morfologi debunga yang hadir pada beberapa spesies kajian iaitu ciri kelas debunga (Guioa pleuropteris) dan julat d/D butir debunga (Lepisanthes tetraphylla) yang boleh dijadikan panduan untuk pengecaman spesies secara langsung menggunakan ciri morfologi debunga.

\section{KESIMPULAN}

Hasil kajian morfologi debunga yang dijalankan ke atas enam spesies Sapindaceae ini menunjukkan variasi ciri morfologi debunga yang agak tinggi terutama pada peringkat spesies dan genus. Gabungan ciri morfologi debunga seperti kelas debunga, saiz debunga, bentuk debunga, julat d/D serta hiasan eksin dapat membantu dalam mengukuhkan lagi data untuk pengelasan spesies kajian. Hasil analisis menunjukkan bahawa ciri morfologi debunga menepati pengelasan dan kedudukan spesies untuk genus tropika. Analisis dan lebih banyak spesies kajian morfologi debunga famili Sapindaceae perlu dilakukan di kawasan tropika khususnya di Malaysia untuk mendapatkan gambaran yang lebih jelas mengenai kepelbagaian morfologi dan mikromorfologi debunga famili Sapindaceae.

\section{PENGHARGAAN}

Penghargaan ditujukan khusus kepada En. Masrom Hasran dan Pn. Salmaniza Salleh atas bantuan pengumpulan sampel di lapangan dan kerja-kerja makmal palinologi di 
Kompleks MyGeneBank, MARDI Serdang. Penghargaan turut ditujukan kepada Herbarium Universiti Kebangsaan Malaysia (UKMB) dan Unit Mikroskopi Elektron, Universiti Kebangsaan Malaysia atas kerjasama dan kebenaran menjalankan analisis spesimen serta cerapan mikromorfologi debunga. Penghargaan khas ditujukan kepada Institut Penyelidikan dan Kemajuan Pertanian Malaysia (MARDI) atas bantuan pembiayaan kajian ini.

\section{RUJUKAN}

Adema, F., Leenhouts, P.W. \& van Welzen, P.C. 1996. Sapindaceae. Dlm. Tree Flora of Sabah and Sarawak 2, Soepadmo, E., Wong, K.M. \& Saw, L.G. (Eds). Kuala Lumpur: Forest Research Institute Malaysia. hlm. 263-374.

Ashton, P.S. 1982. Dipterocarpaceae. Dlm. Flora Malesiana 1 - Spermatophyta (Seed Plant), van Steenis, C.G.G.J. (Ed.) Leiden: Foundation Flora Malesiana. hlm. 237-552.

Avecedo-Rodriguez, P. 2003. Melicocceae (Sapindaceae): Melicoccus and Talisia. Flora Neotropica 87: 1-179.

Avecedo-Rodriguez. P. 1993. Systematics of Serjania (Sapindaceae).Part I: A revision of Serjania Sect. Platycoccus. Memoir of New York Botanical Garden 67: 1-93.

Avecedo-Rodriguez, P., van Welzen, P.C., Adema, F. \& van der Ham, R.W.J.M. 2011. Sapindaceae. Dlm The Families and Genera of Vascular Plants 10 - Eudicots: Sapindales, Cucurbitales, Myrtaceae, Kubitzki, K. (Ed.) Berlin: Springer Press Publication. hlm. 357-407.

Buerki, S., Forest, F., Acevedo-Rodríguez, P., Callmander, M.W., Nylander, J.A.A., Harrington, M., Sanmartin, I., Küpfer, P. \& Alvarez, N. 2009. Plastid and nuclear DNA markers reveal intricate relationships at subfamilial and tribal levels in the soapberry family (Sapindaceae). Molecular Phylogenetics and Evolution 51: 238-258.

Eide, F. 1981. Key for the Northwest European Rosaceae pollen. Grana 20: 101-118.

Erdtman, G. 1952. Pollen Morphology and Plant Taxonomy: Angiosperms - An Introduction to Palynology. New York: The Chronica Botanica Company.

Erdtman, G. 1969. Handbook of Palynology: Morphology, Taxonomy, Ecology: An Introduction to the Study of Pollen Grains and Spores. New York: Hafner Publishing Co.

Faegri, K. \& Iversen, J. 1992. Textbook of Pollen Analysis. Chichester: John Wiley \& Sons.

Ferrucci, M.S. \& Anzotegui, L.M. 1993. El polen de Paullinieae (Sapindaceae). Bonplandia 6: 211-243.

Fogle, H.W. 1977. Identification of clones within 4 tree species by pollen exine patterns. Journal of American Society of Horticultural Science 102: 552-560.

Furness, C. 1989. The pollen morphology of Ecbolium and Megalochlamys (Acanthaceae). Kew Bulletin 44(4): 681-693.

Hesse, H.M., Zetter, R., Weber, M., Buchner, R., Frosch, R.A. \& Ulrich, S. 2009. Pollen Terminology: An Illustrated Handbook. New York: Springer Publication.

Kremp, G.O.W. 1965. Encyclopaedia of Pollen Morphology. Tuscon, USA: University Arizona Press.

Moore, P.D., Webb, J.A. \& Collinson, M.E. 1991. Pollen Analysis. Edisi ke-2. London: Blackwell Scientific Publications.

Muller, J. 1979. Form and function in angiosperm pollen. Annals Missouri Botanic Gardens 66: 592-632.

Muller, J. \& Leenhouts, P.W. 1976. A general survey of pollen types in Sapindaceae in relation to taxonomy. Dlm The
Evolutionary Significance of the Exine. Linnean Society Symposium Siri 1, Ferguson, I.K. \& Muller, J. (Eds.). London: Academic Press. hlm. 407-445.

Noraini, T. 2008. Systematic significance of pollen morphology of Shorea, Hopea, Parashorea and Neobalanocarpus (Dipterocarpaceae) in Malaysia. Sains Malaysiana 37(2): 169-176.

Noraini, T. 2006. Systematic study of Shorea, Hopea, Parashorea and Neobalanocarpus (Dipterocarpaceae) in Malaysia. Tesis Doktor Falsafah, University of Reading (Tidak diterbitkan).

Nowicke, J.W. \& Skvarla, J.J. 1979. Pollen morphology: The potential influence in higher order systematics. Annals of the Missouri Botanical Garden 66: 633-700.

Ortrud, M.B. \& Cynthia, F.P. 2014. Pollen morphology of Vochysiaceae tree species in the state of Santa Catarina, Southern Brazil. Review of Biology Tropical 62(3): 12091215.

Punt, W., Blackmore, S., Nilsson, S. \& Thomas, A.L. 1994. Glossary of Pollen and Spore Terminology. Netherland: University of Utrecht Publisher.

Radlkofer, L. 1934. Sapindaceae. Dlm Das Pfanzenreich IV, Engler, A. (Ed.). Leipzig: W. Engelmann Press. hlm. 1-1539.

Reitsma, T.J. 1966. Pollen morphology of some European Rosaceae. Acta Botanica Neerlandica 15: 290-379.

Thorne, R.F. \& Reveal, J.L. 2007. An updated classification of the class Magnoliosida (Angiospermae). Botanical Review 73: $67-182$.

Shinwari, M. \& Khan, M.A. 2004. Pollen morphology of wild roses from Pakistan. Hamdard Medicus 474: 5-13.

van der Ham, R.W.J.M. 1990. Nephelieae Pollen (Sapindaceae): Form, Function, and Evolution. Leiden: National Herbarium Netherlands.

Wang, F.H. \& Chien, N.F. 1956. A contribution to the pollen morphology of Sapindaceae. Acta Botany Sinica 5: 327-338.

Wronska-Pilarek, D. \& Lira, J. 2006. Pollen morphology of Polish species of the genus Rosa L. - Rosa pendulina L. Dendrobiology 55: 65-73.

Wronska-Pilarek, D. \& Boraynska, K. 2005. Pollen morphology of Rosa gallica L. Rosaceae L. from Southern Poland. Acta Societatis Botanicorum Poloniae 744: 297-304.

Xia, N. \& Gadek, P.A. 2007. Sapindaceae. Dlm Flora of China, Zhengyi, W., Raven, P.H. \& Deyuan, H. (Eds.). Beijing: St. Louis, Missouri Botanical Garden Press. hlm. 5-24.

Mohd. Norfaizal Ghazalli*, Mohd. Shukri Mat Ali \& Nurshahidah Mohd Rusli

Program Pengurusan dan Pemuliharaan Sumber Genetik Tumbuhan

Pusat Bank Gen dan Biji Benih

Ibu Pejabat MARDI, Persiaran MARDI-UPM

43400 Serdang, Selangor Darul Ehsan

Malaysia

Mohd. Norfaizal Ghazalli*, Noraini Talip \& A. Latiff

Pusat Pengajian Sains Sekitaran dan Sumber Alam

Fakulti Sains dan Teknologi

Universiti Kebangsaan Malaysia

43600 UKM Bangi, Selangor Darul Ehsan

Malaysia

Ahmad Zaki Zaini

Unit Mikroskopi Elektron 
Fakulti Sains dan Teknologi Universiti Kebangsaan Malaysia

43600 UKM Bangi, Selangor Darul Ehsan

Malaysia

*Pengarang untuk surat-menyurat; email: mnfaizal@mardi.

gov.my
Diserahkan: 16 Mei 2018

Diterima: 2 Januari 2019 